\title{
Directed mutagenesis affects recombination in Azospirillum brasilense nif genes
}

\author{
C.P. Nunes ${ }^{2}$, L.M.P. Passaglia ${ }^{2}$, A. Schrank ${ }^{1}$ and I.S. Schrank ${ }^{1}$
}

\begin{abstract}
In order to improve the gene transfer/mutagenesis system for Azospirillum brasilense, gene-cartridge mutagenesis was used to replace the nif $\mathrm{D}$ gene with the Tn5 kanamycin resistance gene. The construct was transferred to A. brasilense by electrotransformation. Of the 12 colonies isolated using the suicide plasmid pSUP202 as vector, only four did not show vector integration into the chromosome. Nevertheless, all 12 colonies were deficient in acetylene reduction, indicating an Nif - phenotype. Four Nif- mutants were analyzed by Southern blot, using six different probes spanning the nif and $\mathrm{Km}^{\mathrm{r}}$ genes and the plasmid vector. Apparently, several recombination events occurred in the mutant genomes, probably caused mainly by gene disruption owing to the mutagenesis technique used: resistance genecartridge mutagenesis combined with electrotransformation.
\end{abstract}

\section{INTRODUCTION}

Azospirillum brasilense can grow diazotrophically using a molybdenum-dependent nitrogenase. Nitrogenase, the enzyme that catalyses biological nitrogen fixation, consists of two protein components: iron and molybdenum iron. Native Fe protein is a homodimer of approximately $68-\mathrm{kDa}$ subunits, while the MoFe protein is a tetrameric complex with four [4Fe-4S] centers and two iron-molybdenum cofactors (Dixon, 1984; Haaker and Veeger, 1984). In most $\mathrm{N}_{2}$-fixing organisms, the nitrogenase structural genes are organized in a single operon and transcribed in the order nifH-D-K (Arnold et al., 1988; Jacobson et al., 1989; Willison et al., 1993). The nifH gene codes for subunits of the Fe protein and for the MoFe protein nifD, and nifK genes code for $\alpha$ and $\beta$ subunits, respectively. Transcription of these genes, in general, is repressed by both $\mathrm{NH}_{4}{ }^{+}$and $\mathrm{O}_{2}$, and occurs only under nitrogen-limiting conditions (Nelson and Knowles, 1978; Postgate and Cannon, 1981).

Azospirillum spp. fix nitrogen under free-living conditions and in association with grasses. The nif structural genes from $A$. brasilense have been sequenced and present the same sequential organization found in other nitrogenfixing bacteria (Passaglia et al., 1991). Analysis of the molecular genetics of nitrogen fixation in A. brasilense revealed a 45-kb DNA region, comprised of the nifENXO RF3ORF5ORF6Q, ORF2nifUSVORF4 and fix ABC operons located, 3,11 , and $15 \mathrm{~kb}$, respectively, downstream from the nifHDKORF1Y operon (Passaglia, L., Frazzon, J. and Vedoy, C., unpublished results).

After the report of Elmerich and Franche (1982) on Tn5-induced auxotroph mutants in A. brasilense, different protocols have been suggested for increasing the efficiency of transposon mutagenesis in this organism. The suicide plas- mid pSUP202 was used successfully to deliver $\operatorname{Tn} 5$ into the Azospirillum genome (Singh and Klingmüller, 1986; AbdelSalam and Klingmüller, 1987; Faure et al., 1994). Plasmids of the P incompatibility group can also be transferred to $A$. brasilense, and plasmid pRK290 has been used as a vector to isolate $\mathrm{Nif}^{-}$mutants of $A$. brasilense (Jara et al., 1983).

We established an efficient gene disruption system for inducing site-specific mutations in A. brasilense, and then used it to isolate NifD mutants.

\section{MATERIAL AND METHODS}

Bacterial strains, growth conditions and
nitrogenase derepression

Several E. coli strains and one A. brasilense strain were used (Tables I and II). Growth of $E$. coli strains carrying either hybrid nif-containing plasmids or vectors, and preparation, restriction enzyme digestion, and ligation of hybrid plasmid DNAs were performed as described previously (Sambrook et al., 1989). The wild-type and mutant strains of $A$. brasilense were cultured in Nfb medium (Ditta et al., 1980) supplemented with ammonium chloride to a final concentration of $40 \mathrm{mM}$, when a fixed source of nitrogen was introduced into the medium. For nitrogenase synthesis induction, all cultures were grown in nitrogenfree $\mathrm{Nfb}$ medium for $24 \mathrm{~h}$. In vivo nitrogenase activity was measured by $\mathrm{C}_{2} \mathrm{H}_{2}$ reduction in nitrogen-free, semi-solid $\mathrm{Nfb}$ medium (0.175\% agar) (Nelson and Knowles, 1978).

\section{Bacterial mating and electroporation}

The A. brasilense cultures were grown overnight at $30^{\circ} \mathrm{C}$ in LB broth to a density of $10^{8}$ cells $/ \mathrm{ml}$. The E. coli

\footnotetext{
${ }^{\prime}$ Departamento de Biologia Molecular e Biotecnologia, and ${ }^{2}$ Departamento de Genética, Centro de Biotecnologia, UFRGS,

Av. Bento Gonçalves, 9500 P.43421, Caixa Postal 15005, 91501-970 Porto Alegre, RS, Brasil. Send correspondence to I.S.S. Fax: +55-51-336-2779. E-mail: irene@dna.cbiot.ufrgs.br
} 
Table I - Bacterial strains used in the present study.

\begin{tabular}{|c|c|c|c|}
\hline Bacteria & Strain & Relevant characteristics & Source/reference \\
\hline \multirow[t]{3}{*}{ Escherichia coli } & JA221 & $\operatorname{rec} \mathrm{A}$, leuB6, $\operatorname{trp} \mathrm{ES}, h s d \mathrm{R}^{-}, h s d \mathrm{M}^{+}$, lac $\mathrm{Y}$ & Clark and Carbon, 1978 \\
\hline & TG2 & sup $\mathrm{E}, h s d \mathrm{D} 5$, thi, $\mathrm{D}($ lac-pro $\mathrm{AB}),(s r l-r e c \mathrm{~A}) 306:: \operatorname{Tn} 10\left(t e t^{r}\right)$ & Sambrook et al., 1989 \\
\hline & S17.1 & rec $\mathrm{A}$, thi, pro, hsd $\mathrm{R}^{-}, h s d \mathrm{M}^{+}, \mathrm{Sm}^{\mathrm{r}}$ & Simon et al., 1983 \\
\hline \multirow[t]{2}{*}{ Azospirillum brasilense } & $\mathrm{Sp} 7$ & $\mathrm{Amp}^{\mathrm{r}}$, wild-type & ATCC29145 \\
\hline & Sp7Nif -10 & $\mathrm{Amp}^{\mathrm{r}}, \mathrm{Km}^{\mathrm{r}}$, nifD-mutant & This work \\
\hline
\end{tabular}

Table II - Plasmids used in the present study.

\begin{tabular}{|c|c|c|}
\hline Plasmids & Relevant characteristics & Source/reference \\
\hline pRK290X & $\mathrm{Tc}^{\mathrm{r}}$, incP, $\mathrm{Tra}^{-}$ & $\begin{array}{l}\text { Alvarez-Morales } \\
\text { et al., } 1986\end{array}$ \\
\hline pRK2013 & $\mathrm{Km}^{\mathrm{r}}$, colicine E1, $\mathrm{Tra}^{+}$ & Ditta et al., 1980 \\
\hline pPH1JI & $\mathrm{Gm}^{\mathrm{r}}$, incP, Tra $^{-}$ & Ditta et al., 1980 \\
\hline pSUP202 & $\mathrm{Tc}^{\mathrm{r}}, \mathrm{Amp}^{\mathrm{r}}, \mathrm{Cm}^{\mathrm{r}}, \mathrm{Mob}^{+}$ & Simon et al., 1983 \\
\hline \multirow[t]{2}{*}{ pAbc6 } & $\mathrm{pACYC} 184+6.5-\mathrm{kb}$ & \\
\hline & EcoRI nifHDK region & This lab. \\
\hline pRKm6X & $\mathrm{Tc}^{\mathrm{r}}, \mathrm{Km}^{\mathrm{r}}$, incP, Tra $^{-}$ & This paper \\
\hline pSUP6 & $\mathrm{Tc}^{\mathrm{r}}, \mathrm{Km}^{\mathrm{r}}, \mathrm{Amp}^{\mathrm{r}}, \mathrm{Mob}^{+}$ & This paper \\
\hline pKm6 & $\mathrm{Tc}^{\mathrm{r}}, \mathrm{Km}^{\mathrm{r}}$ & This paper \\
\hline
\end{tabular}

donor cells were grown at $37^{\circ} \mathrm{C}$ overnight in LB broth, diluted 10-fold, and grown for another $2 \mathrm{~h}$ to exponential phase. Samples of donor and acceptor cells (1:3 ratio) were passed through nitrocellulose filters, placed on LB agar plates, and incubated for $16 \mathrm{~h}$ at $30^{\circ} \mathrm{C}$. Filters containing either donor or recipient cells were incubated as controls. Conjugation and control growth patches were resuspended in $0.85 \% \mathrm{NaCl}$ solution, washed several times, diluted, and spread on selective plates. The pRK290X derivative pRKm6X was mobilized into $A$. brasilense by triparental mating, as described by Ditta et al. (1980). Mutants, in which the wild-type region is to be replaced with the mutated DNA fragment, should be obtained by introducing the IncP1 plasmid pPH1J1 into the pKRm6X-carrying $A$. brasilense strain, followed by selection on both kanamycin and gentamycin. $\mathrm{Km}^{\mathrm{r}}$ exconjugants were selected on minimal $\mathrm{Nfb}$ medium supplemented with $\mathrm{NH}_{4}{ }^{+}$and $30 \mu \mathrm{g} /$ $\mathrm{ml}$ of kanamycin.

Electroporation of A. brasilense was carried out using the Gene Pulser Apparatus (Bio-Rad). The procedure used was based on the method described by Vande Broek $e t$ al. (1989). The pSUP202 suicide derivative pSUP6 was electrotransferred to A. brasilense and transformants were selected for kanamycin resistance. Plasmid pRK290X was used as control.

\section{Hybridization procedures}

${ }^{32} \mathrm{P}$-labelled probes were prepared by nick translation (Sambrook et al., 1989). Southern hybridization was carried out at $68^{\circ} \mathrm{C}$ under conditions described previously
(Singh and Klingmüller, 1986). To verify results of marker exchange, total DNA was isolated from putative mutants, digested with the appropriate restriction enzyme and hybridized against labelled DNA fragments.

\section{Plasmid constructions}

A. brasilense nitrogenase structural genes have already been isolated, and their complete nucleotide sequence has been determined. These genes are clustered and arranged in the nifHDKORF1 $Y$ operon. To construct pKm6, DNA from the pAbc6 plasmid was digested with PstI and the 2.4$\mathrm{kb}$ nifD DNA fragment was replaced with a 1.9-kb PstIDNA fragment originating from partially digested Tn5 DNA (Beck et al., 1982). The 6.0-kb EcoRI DNA fragment, carrying the $\mathrm{Km}^{\mathrm{r}}$-cartridge from the $\mathrm{pKm} 6\left(\right.$ nifHKm$^{\mathrm{r}} \mathrm{K}$ ) plasmid, was subcloned into either EcoRI-digested pRK290X or pSUP202 plasmid vectors, generating plasmids pRKm6X and pSUP6, respectively.

\section{RESULTS AND DISCUSSION}

\section{Isolation of $A$. brasilense nif mutants}

The A. brasilense nitrogenase structural genes are clustered and arranged as follows: promoter-nifH-nifDnifK in a 6.5-kb EcoRI DNA fragment (Figure 1). This DNA fragment was originally cloned into an EcoRI-digested pACYC184 vector yielding pAbc6 (Araújo et al., 1988). Since pACYC184 has no PstI sites, it was possible to replace the nifD gene with a $\mathrm{Km}^{\mathrm{r}}$-cartridge from $\mathrm{Tn} 5$ (Figure 1). In the resulting pKm6 plasmid, the $\mathrm{Km}^{\mathrm{r}}$-cartridge is flanked by $1.7-\mathrm{kb}$ and $2.3-\mathrm{kb}$ DNA fragments from the $A$. brasilense nifHDK cluster. The size of these fragments should be sufficient to direct homologous recombination into the $A$. brasilense genome, yielding Nif $^{-}$mutants with a deleted nifD gene. To date, mutagenized plasmids have been transferred to $A$. brasilense only by conjugation (Elmerich and Franche, 1982; Singh and Klingmüller, 1985; Vanstockem et al., 1987). However, Vande Broek et al. (1989) developed an electroporation protocol for DNA delivery into $A$. brasilense. We used both conjugation and electroporation techniques to isolate $\mathrm{Nif}^{-}$mutants from A. brasilense.

Typical mating conditions are outlined in Material and Methods. The A. brasilense strain used as DNA acceptor 


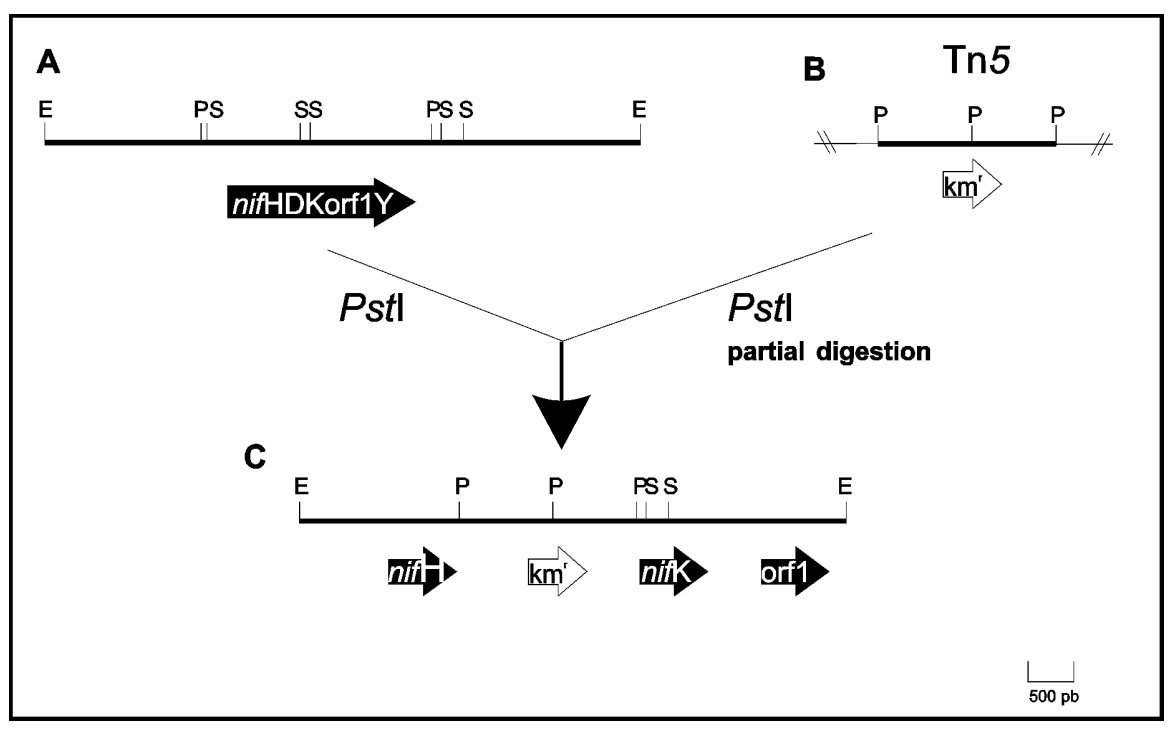

Figure 1 - Strategy for constructing the gene replacement cartridge. A) Physical map of the Azospirillum brasilense nif structural gene cluster. B) Partial physical map of the $\operatorname{Tn} 5$ transposon. C) Physical map of the pKm6 plasmid containing the nif $\mathrm{D}$ gene replaced with the $\mathrm{km}^{\mathrm{r}}$-cartridge. is resistant to ampicillin up to $200 \mu \mathrm{g} / \mathrm{ml}$ and very sensitive to kanamycin (less than $5 \mu \mathrm{g} / \mathrm{ml}$ ). Spontaneous mutants resistant to kanamycin $(25 \mu \mathrm{g} / \mathrm{ml})$ were undetected in control experiments. In order to generate $A$. brasilense NifD $^{-}$mutants we used two different plasmids: pRKm6X and pSUP6. In the first experiment, nifHKm${ }^{\mathrm{r}} \mathrm{K}$ mutagenized genes were transferred to the wild-type strain and the stable replicating vector (pRK290X) was removed using another plasmid belonging to the same incompatibility group (pPH1), thus making it easier to detect the mutagenized phenotype. Azospirillum exconjugants bearing pRKm6 were isolated on $\mathrm{Nfb}$ medium containing $30 \mu \mathrm{g} / \mathrm{ml} \mathrm{kana-}$ mycin at maximum frequencies of $10^{-8}$ per recipient cell. Several experiments of triparental mating were carried out to remove the replicating vector and to generate $\mathrm{Nif}^{-}$ mutants. A. brasilense $\mathrm{Sp} 7$ carrying pRKm6X was used as acceptor and E. coli strains JA221, carrying pPH1 $\left(\mathrm{Gm}^{\mathrm{r}}\right)$, and JA221, carrying pRK2013, were used as donors. Approximately 60,000 colonies were screened for $\mathrm{Km}^{\mathrm{r}}$ and $\mathrm{Gm}^{\mathrm{r}}$ transconjugants, all of which were also resistant to tetracycline $\left(\mathrm{Tc}^{\mathrm{r}}\right)$, indicating that $\mathrm{pRKm} 6 \mathrm{X}$ had integrated into the A. brasilense chromosome (cointegrate formation). Singh and Klingmüller (1986) have also reported a failed attempt to isolate $\mathrm{Nif}^{-}$mutants using the stable replicative plasmid vector pRK290. In addition, we used vectors which were unable to replicate in the recipient bacterium and which were lost after transfer into the recipient cell.

The narrow host range plasmid pSUP202, a mobilizable derivative of $\mathrm{pBR} 325$, was transferred to A. brasilense using the special mobilizing E. coli strain S17.1 (Simon et al., 1983). This strain has the RP4 plasmid integrated into its chromosome and hence can mobilize plasmids having the same $m o b$ site of IncP plasmids as pSUP202 (Simon et al., 1983). After mating E. coli S17.1 (bearing pSUP6) with $A$. brasilense, $\mathrm{Km}^{\mathrm{r}}$ plus $\mathrm{Ap}^{\mathrm{r}}$ exconjugants were selected on $\mathrm{Nfb}$ minimum medium. Although a transfer frequency of $10^{-7}$ per recipient cell was achieved, we were unable to isolate any transconjugant sensitive to tetracycline $\left(\mathrm{Tc}^{\mathrm{s}}\right)$. The results obtained with pSUP6 also indicated its integration into the A. brasilense chromosome.

Successful mutagenesis of $A$. brasilense using conjugation methods has been reported previously (Elmerich and Franche, 1982; Abdel-Salam and Klingmüller, 1987; Singh and Klingmüller, 1986; Vanstockem et al., 1987), and has been achieved using either stable replicative or suicide vectors and transposon $\mathrm{Tn} 5$ as the mutagenic element. We failed to isolate mutants from $A$. brasilense using this method. However, we then used a resistance gene-cartridge mutagenesis technique instead of transposon Tn5, which involved the cloning of a DNA fragment containing an antibiotic resistance gene into the genes to be mutagenized. Since the $\mathrm{Km}^{\mathrm{r}}$-cartridge is unable to transpose, no interference occurs due to further transposition in the recipient cell genome.

Transformation of Azospirillum by electroporation has proven to be an efficient method for DNA transfer in this bacterium (Vande Broek et al., 1989), and the feasibility of electrotransformation of A. brasilense Sp7 with pSUP6 was analyzed as outlined in Material and Methods, using the broad host range plasmid pRK290X as control throughout the study. Under these conditions $12 \mathrm{Ap}^{\mathrm{r}}$ plus $\mathrm{Km}^{\mathrm{r}}$ colonies were obtained. To determine the integration of the $\mathrm{Km}^{\mathrm{r}}$-cartridge into the A. brasilense chromosome, we assayed the colonies for tetracycline resistance. Four out of 12 colonies tested did not acquire pSUP202-encoded tetracycline resistance, confirming the absence of the vector DNA which was further confirmed by the absence of hybridization between total DNA from the transformants and ${ }^{32} \mathrm{P}$-labelled pSUP202 plasmid DNA. The remaining eight colonies were $\mathrm{Tc}^{\mathrm{r}}$, indicating that, since this marker is coded by a non-transposable gene present in the pSUP202 
vector, pSUP202 had been integrated into the genome. This was confirmed by the absence of free plasmid DNA corresponding in size to pSUP202 and by positive hybridization on a Southern blot of total DNA from transformants probed with the vector (data not shown).

When the 12 potential Nif $^{-}$mutants isolated were assayed for acetylene-reducing activity they proved to be completely deficient (0.02-0.4\% of wild-type total activity), confirming a $\mathrm{Nif}^{-}$phenotype for all isolated transformants.

\section{Physical analysis of A. brasilense mutants}

To further characterize the mutagenized 6.5-kb EcoRI A. brasilense genomic region, total DNA from the $12 \mathrm{Ap}^{\mathrm{r}}$ and $\mathrm{Km}^{\mathrm{r}}$ mutants isolated after electroporation was analyzed by Southern blot. Total DNA was digested with EcoRI and hybridized against the ${ }^{32} \mathrm{P}$-labelled 6.5-kb EcoRI fragment isolated from the wild-type $A$. brasilense nifHDK DNA region. Hybridization was detected only in genomes of the four $\mathrm{Ap}^{\mathrm{r}}, \mathrm{Km}^{\mathrm{r}}$ and $\mathrm{Tc}^{\mathrm{s}}$ mutants (data not shown). Due to lack of hybridization of the remaining eight $\mathrm{Nif}^{-}$mutants, we further analyzed only the four mutants that did not show vector integration. Therefore, total DNA from Sp7Nif ${ }^{-}$9, Sp7Nif- 10, Sp7Nif- 11, and Sp7Nif- 13 was digested with EcoRI and hybridized against the 6.0-kb EcoRI fragment isolated from the pKm6 plasmid (Figure 1). Only one band of $4.0 \mathrm{~kb}$ was visualized in strain Sp7Nif- 10 (Figure

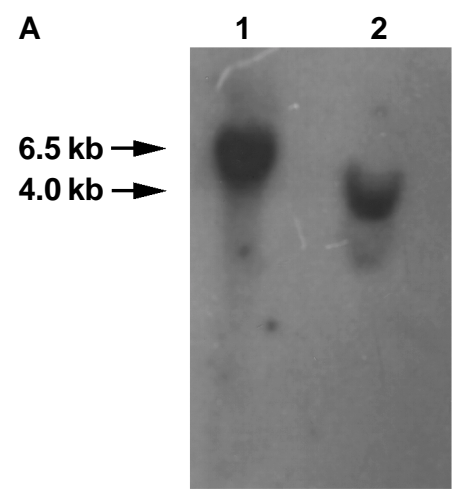

B
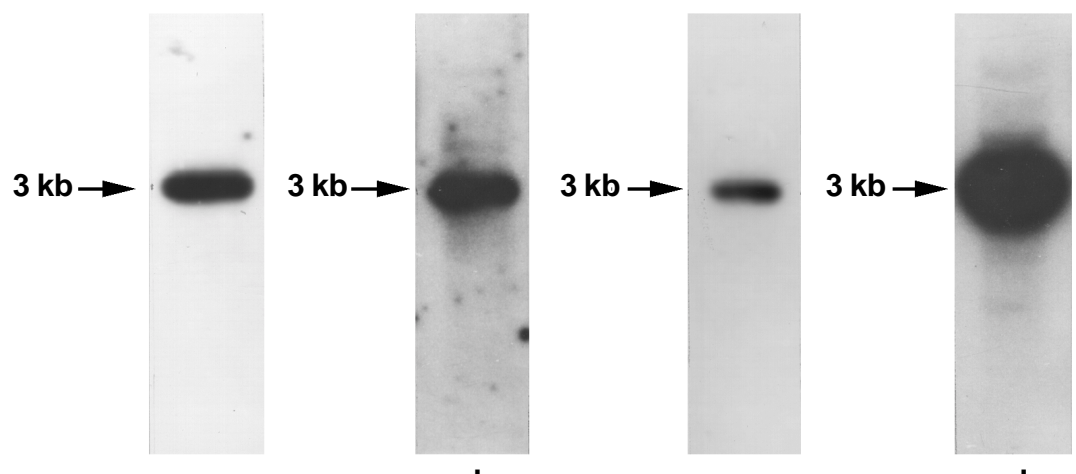

C b d
2A, lane 2), showing that after the recombination event nif $\mathrm{HKm}^{\mathrm{r}} \mathrm{K}$ genes were no longer intact in this mutant. With wild-type DNA a $6.5-\mathrm{kb}$ band representing the nifHDK genes was visualized (Figure 2A, lane 1). In the other three recombinants only faint bands were visualized.

To determine the presence of Tn 5 in all 12 mutants, total DNA was digested with PstI and hybridized against the 0.9- and 1.0-kb PstI fragments of Tn5. No hybridization was detected (data not shown), suggesting that the mutants had lost the Tn5 DNA fragment, a fact probably explaining the weak hybridization signal obtained when the 6.0-kb EcoRI fragment isolated from the pKm6 plasmid was used as probe.

To further analyze the recombination events that occurred in the Sp7Nif- 10 mutant, total DNA was digested with PstI and hybridized against four alternative probes (spanning nifHDK, nifH, nifD, or nifK). All four probes hybridized against the same 3.0-kb PstI DNA fragment (Figure 2B), suggesting that several recombination events had occurred. Thus, the Sp7Nif- 10 mutant partially lost both the nifH, nifD, and nifK genes and the entire kanamycin resistance gene.

Narrow host range plasmids, based on pACYC184 and pBR325 replicons, such a pSUP202 plasmid, can be transferred to A. brasilense but are unable to replicate in this bacterium. Such plasmids have been used as suicide vehicles to deliver transposons in Azospirillum and the transposon mutagenesis technique has been efficient in generating different Nif $^{-}$mutants in this bacterium (Elmerich and Franche, 1982; Abdel-Salam and Klingmüller, 1987; Singh and Klingmüller, 1986; Vanstockem et al., 1987). Attempts to use a combination of nif-gene deletion and resistance genecartridge mutagenesis of $A$. brasilense genes have also been successful. However, all mutants have been obtained by transferring the plasmids using conjugation methods, which are problematic because counterselection of the donor strain requires time-consuming rounds of single-colony purification. Moreover, since attempts to transfer plasmid DNA between Azospirillum strains have so far failed, many manipulations involve passage through $E$. coli cells.
Figure 2 - Physical analysis of $\mathrm{Km}^{\mathrm{r}}$-transformants of Azospirillum brasilense. Southern hybridization between Sp7Nif ${ }^{-} 10$ and ${ }^{32} \mathrm{P}$-labelled DNA probes. $\lambda$ DNA digested with HindIII was used as molecular weight standard. A) Total Sp7 DNA (lane 1) and Sp7Nif - 10 DNA (lane 2) digested with EcoRI and hybridized with nifHKm ${ }^{r} \mathrm{~K}$ probe. B) Total Sp7Nif10 DNA digested with PstI and hybridized with nifHDK (a), nifH (b), nifD (c), and nifK (d) probes. 
We have used a novel combination of nifD-gene deletion with kanamycin gene-cartridge mutagenesis and electrotransformation. The method proved to be useful in isolating a number of $A$. brasilense $\mathrm{Nif}^{-}$mutants, all of which were completely defective in nitrogen fixation. However, the technique should be studied in more detail since other genome regions were also lost. Recombination events in A. brasilense are still poorly understood. We suggest that gene disruption combined with electrotransformation is the major cause of genome rearrangements by illegitimate recombination, producing deletions not only of the target gene but also of adjacent regions.

\section{ACKNOWLEDGMENTS}

The authors wish to thank Dr. H. Hennecke for providing the pRK290X and Dr. Fábio Pedrosa for providing pSUP202. C.P.N. received a scholarship from CNPq (Conselho Nacional de Pesquisa-Brasil) which, in addition to FAPERGS, supported this work through grants.

\section{RESUMO}

Com o objetivo de melhorar os sistemas de transferência gênica e mutagênese para Azospirillum brasilense, a técnica de mutagênese através do uso de um gene marcador ("gene-cartridge mutagenesis") foi utilizada para substituir a região genômica de $A$. brasilense correspondente ao gene nifD por um segmento de DNA do transposon $\operatorname{Tn} 5$ contendo o gene que confere resistência ao antibiótico canamicina. A construção foi transferida para a linhagem de A. brasilense por eletrotransformação. Doze colônias transformantes foram isoladas com o plasmídeo suicida pSUP202 servindo como vetor. Dessas, somente quatro não possuíam o vetor integrado no cromossomo da bactéria. Independentemente da integração ou não do vetor, as 12 colônias foram deficientes na redução do gás acetileno, evidenciando o fenótipo Nif ${ }^{-}$. Quatro mutantes Nif - foram analisados através da técnica de Southern blot, utilizando-se seis diferentes fragmentos contendo genes nif, de resistência à canamicina e do vetor como sondas. Os resultados sugerem a ocorrência de eventos recombinacionais variados no genoma dos mutantes. A combinação entre a disrupção gênica através da técnica de mutagênese utilizada e eletrotransformação foi, provavelmente, a causa principal do rearranjo genômico ocorrido nessas bactérias.

\section{REFERENCES}

Abdel-Salam, M.S. and Klingmüller, W. (1987). Transposon Tn5 mutagenesis in Azospirillum lipoferum: isolation of indole acetic acid mutants. Mol. Gen. Genet. 210: 165-170.

Alvarez-Morales, A., Betancourt-Alvarez, M., Kaluza, K. and Hennecke, H. (1986). Activation of the Bradyrhizobium japonicum nifH and nifDK is dependent on promoter-upstream DNA sequences. Nucleic Acids Res. 14: 4207-4227.

Araújo, E.F., Zaha, A., Schrank, I.S. and Santos, D.S. (1988). Characterization of DNA segments adjacents to the nifHDK genes of Azospirillum brasilense Sp7 by Tn5 site-directed mutagenesis. In: Azospirillum IV: Genetics, Physiology and Ecology (Klingmüller, W., ed.). 4th edn.
Proceedings of the Fourth Bayrenth Azospirillum Workshop, Bayrenth, Germany, p. 16.

Arnold, W., Rump, A., Klipp, W., Priefer, O. and Pühler, A. (1988). Nucleotide sequence of a 24,206 base-pair DNA fragment carrying the entire nitrogen fixation gene cluster of Klebsiella pneumoniae. J. Mol. Biol. 203: 715-738.

Beck, E., Ludwig, G., Auerswald, E.A., Reiss, B. and Schaller, H. (1982). Nucleotide sequence and exact localization of the neomycin phosphotransferase gene from transposon Tn5. Gene 19: 327-336.

Clark, L. and Carbon, J. (1978). Functional expression of cloned yeast DNA in Escherichia coli: Specific complementation of Argininosuccinate lyase $(\operatorname{argH})$ mutation. J. Mol. Biol. 120: 517-532.

Ditta, G.S., Stanfield, S., Corbin, D. and Helinski., D.R. (1980). Broad host range DNA cloning system for Gram-negative bacteria: Construction of a gene bank of Rhizobium meliloti. Proc. Natl. Acad. Sci. USA 77: 7347-7351.

Dixon, R.A. (1984). The genetic complexity of nitrogen fixation. J. Gen. Microbiol. 130: 2745-2755.

Elmerich, C. and Franche, C. (1982). Azospirillum Genetics: plasmids, bacteriophages and chromosome mobilization. Physiol. Ecol. 3: 9-17.

Faure, D., Bouillant, M.L. and Bally, R. (1994). Isolation of Azospirillum lipoferum $4 \mathrm{~T} \mathrm{Tn} 5$ mutants affected in melanization and laccase activity. Appl. Environ. Microbiol. 60: 3413-3415.

Haaker, H. and Veeger, C. (1984). Enzymology of nitrogen fixation. Trends Biochem. Sci. 9: 188-192.

Jacobson, M.R., Brigle, K.E., Bennett, L.T., Setterquist, R.A., Wilson, M.S., Cash, V.L., Beynon, J.L., Newton, W.E. and Dean, D.R. (1989). Physical and genetic map of the major nif gene cluster from Azotobacter vinelandii. J. Bacteriol. 171: 1017-1027.

Jara, P., Quiviger, B., Laurent, P. and Elmerich, C. (1983). Isolation and genetic analysis of Azospirillum brasilense Nif- mutants. Can. J. Microbiol. 29: 968-972

Nelson, L.M. and Knowles, R. (1978). Effect of oxygen and nitrate on nitrogen fixation and denitrification by Azospirillum brasilense grown in continuous culture. Can. J. Microbiol. 24: 1395-1403.

Passaglia, L.M.P., Nunes, C.P., Zaha, A. and Schrank, I.S. (1991). The nifHDK operon in the free-living nitrogen-fixing bacteria Azospirillum brasilense sequentially comprises genes H,D,K, a 353-bp ORF and gene Y. Braz. J. Med. Biol. Res. 24: 649-675.

Postgate, J.R. and Cannon, F.C. (1981). The molecular and genetic manipulation of nitrogen fixation. Philos. Trans. R. Soc. Lon. 292: 589-599.

Sambrook, J., Fritsch, E.F. and Maniatis, T. (1989). Molecular Cloning: A Laboratory Manual. Cold Spring Harbor Laboratory Press, Cold Spring Harbor, New York.

Simon, R., Priefer, U. and Pühler, A. (1983). A broad host range mobilization system for in vivo genetic engineering: transposon mutagenesis in Gram negative bacteria. Bio/Technology 1: 784-790.

Singh, M. and Klingmüller, W. (1985). Problems and prospects of sitedirected transposon mutagenesis in Azospirillum. In: Azospirillum III: Genetics, Physiology and Ecology (Klingmüller, W., ed.). Spring Verlag, Heidelberg, Germany, p. 20

Singh, M. and Klingmüller, W. (1986). Transposon mutagensis in Azospirillum brasilense: isolation of auxotrophic and Nif-mutants and molecular cloning of the mutagenized nifDNA. Mol. Gen. Genet. 202: 136-142.

Vande Broek, A., Gool, A.P.V. and Vanderleyden, J. (1989). Electroporation of Azospirillum brasilense with plasmid DNA. FEMS Microbiol. Lett. 61: $177-182$

Vanstockem, M., Michiels, K. and Vanderleyden, J. (1987). Transposon mutagenesis of Azospirillum brasilense and Azospirillum lipoferum: physical analysis of Tn5 and Tn5-mob insertion mutants. Appl. Environ. Microbiol. 53: 410-415.

Willison, J.C., Pierrard, J. and Hübner, P. (1993). Sequence and transcript analysis of the nitrogenase structural gene operon (nifHDK) of Rhodobacter capsulatus: evidence for intramolecular processing of nifHDK mRNA. Gene 133: 39-46.

(Received March 14, 2000) 
